\title{
ACTIVITY OF SELECTED NON-ANTIBIOTIC MEDICINAL PREPARATIONS AGAINST STANDARD MICROORGANISMS INCLUDING BACTERIAL PROBIOTIC STRAINS
}

\author{
HANNA KRUSZEWSKA ${ }^{1 *}$, TOMASZ ZARĘBA ${ }^{1}$, \\ AGNIESZKA KOCISZEWSKA ${ }^{1}$, and STEFAN TYSKI ${ }^{1,2}$
}

${ }^{1}$ National Medicines Institute, Department of Antibiotics and Microbiology, Chełmska 30-34, 00-725 Warsaw, Poland

${ }^{2}$ Medical University of Warsaw, Department of Pharmaceutical Microbiology,

Oczki 3, 02-007 Warsaw, Poland

\begin{abstract}
The aim of this study was to detect and characterize the antimicrobial activity of non-antibiotic drugs selected from the pharmaceutical products analyzed during the state control performed by the National Medicines Institute, Warsaw, Poland. Pharmaceutical preparations were randomly chosen from different therapeutic groups of drugs. A surveillance study was performed on standard ATCC microbial strains used for drug control: Bacillus subtilis, Staphylococcus aureus, Escherichia coli, Pseudomonas aeruginosa, Candida albicans, Aspergillus brasiliensis, and additionally three Lactobacillus probiotic strains: L. plantarum, L. rhamnosus, L. acidophilus, which revealed that the following active substances, present in medicinal products, inhibited the growth of at least four of the above strains at concentrations below $0.8 \mathrm{mg} / \mathrm{mL}$ : aceclofenac, propafenone, duloxetine, amlodipine, and hydroxyanthracene derivatives.
\end{abstract}

Keywords: non-antibiotics, drugs, antimicrobial activity, Bacillus subtilis, Staphylococcus aureus, Escherichia coli, Pseudomonas aeruginosa, Candida albicans, Aspergillus brasiliensis, Lactobacillus spp., probiotic strains

A great variety of compounds that do not belong to the antibiotics or chemotherapeutics groups, such as anesthetics, diuretics, anticoagulants, antihypertensive and mucolytic drugs, have shown some antimicrobial activity $(1,2)$. These drugs have been described as "non-antibiotics". The antimicrobial activity of non-antibiotics may be related to disruption of the bacterial cell wall structure, ion transport, or enzyme activity, among others. By the end of the nineteenth century, some dyes (e.g., methylene blue) were used as antimicrobial agents (3). A large amount of attention was also focused on thioxanthenes and phenothiazines as compounds affecting cellular transport systems (4). Great progress in antimicrobial treatment efficacy was impaired by the spread of different mechanisms of microbial resistance, and non-antibiotics might themselves be effective or enhance the activity of certain antibiotics. The synergy between conventional antibiotics (aminoglycosides, beta-lactams, tetracyclines, and quinolones) and non-antibiotics (calcium antagonists, antihistamines, diuretics, and neurotropic compounds) has been shown. Strong synergy was observed for certain drug combinations, e.g., diclofenac and streptomycin, propranolol and tobramycin, promazine and tetracycline, chlorcyclizine and ciprofloxacin, and trimeprazine and sulfathiazole, when used simultaneously $(5,6)$.

The involvement of the National Medicines Institute, Warsaw, Poland, in the control of drugs from different groups of pharmaceutical products resulted in the discovery of antimicrobial activity by some of these active substances (7-14). The studies were carried out using standard microbial strains: Bacillus subtilis, Staphylococcus aureus, Escherichia coli, Pseudomonas aeruginosa, Candida albicans, and Aspergillus brasiliensis from known international collections. Growth inhibition has been found for at least one of the examined strains using products containing the following active substances: acepromazine, amitriptyline, butorphanol, cisapride, cisplatin, clomipramine, diltiazem, emedastine,

* Corresponding author: e-mail: h.kruszewska@nil.gov.pl 
fluvastatin, ketamine, levocabastine, metipranolol, methotrexate, perphenazine, proxymetacaine, sertraline, tegaserod, tetrahydrozoline, tropicamide, etc. (7-14). The list of non-antibiotics was extended by Gocmen et al. (15) to include therapeutics belonging to the anesthetics (e.g., bupivacaine, lignocaine, tramadol, and ropivacaine). Moreover, Laudy et al. (16) found that some nonsteroidal anti-inflammatory drugs: diclofenac, mefenamic acid, ibuprofen, and acetylsalicylic acid, were substrates for efflux pumps in Gram-negative rods and, additionally, acetylsalicylic acid-induced efflux-mediated resistance to fluoroquinolones in a few E. coli strains. Furthermore, it was shown that the non-antibiotic active substances: amitriptyline, alendronate, ticlopidine, and nicergoline were actively removed by the efflux pumps present in the cells of Enterobacterales as well as nonfermentative Gram-negative rods (17).

The aim of this study was to further the research of non-antibiotics from different groups of pharmaceutical products present on the Polish pharmaceutical market. In this study, for the first time, three probiotic Lactobacillus spp. strains were also included. These symbiotic bacteria belong to the group of probiotic microorganisms and may have beneficial effects on the health of humans and/or animals. Probiotic microorganisms stimulate nonspecific immune responses with increases of $\operatorname{IgA}$, IgG, and IgM levels, and also enhance intestinal functional maturation, help eradicate Helicobacter pylori and other pathogens, and prevent or treat a range of intestinal maladies, including inflammatory bowel disease, constipation, and colon cancer (18-19). These positive effects are related to the production of organic acids, lipopeptides, bacteriocins, and anti-adherent biosurfactant proteins, among others, which may affect inhibition of biofilm formation by pathogenic bacteria, e.g., multidrug-resistant $P$. mirabilis in the urinary tract (20) or S. mutans in caries (21). Due to these valuable features of probiotic strains, relating not only to the protection of the digestive system with antibiotic therapy but also overall health improvement, their consumption is increasing (22-23). In our work, we focus on explaining whether probiotic bacterial growth may be inhibited by non-antibiotic compounds, potentially affecting the normal microbiota population in the gastrointestinal tract.

\section{EXPERIMENTAL}

The following standard strains were obtained from the American Type Culture Collection: Bacillus subtilis ATCC 6633, Staphylococcus aureus ATCC 6538, Escherichia coli ATCC 8739, Pseudomonas aeruginosa ATCC 15442, Candida albicans ATCC 10231, Aspergillus brasiliensis ATCC 16404, as were three Lactobacillus strains with documented probiotic properties: Lactobacillus plantarum ATCC 14917 (23-24), Lactobacillus rhamnosus ATCC 53103 (19) and Lactobacillus acidophilus ATCC 4356 (22).

The following pharmaceutical products present on the Polish market were chosen for the investigations: Acard $75 \mathrm{mg}$ tab. (acetylsalicylic acid), Amlopin $10 \mathrm{mg}$ tab. (amlodipine), Amsulgen $400 \mathrm{mg}$ tab. (amsulpride), Anulin $100 \mathrm{mg}$ tab. (nimesulide), Apo-Flutam $250 \mathrm{mg}$ tab. (flutamide), Azathioprine VS $50 \mathrm{mg}$ tab. (azathioprine), Betaxomyl $20 \mathrm{mg}$ tab. (betaxolole $\mathrm{HCl}$ ), Blopress Comp Forte $16 \mathrm{mg}$ tab. (candesartan), Butagran Equi $200 \mathrm{mg} / \mathrm{g}$ powder in sachets (phenylbutazon), Cavinton Forte $10 \mathrm{mg}$ tab. (vinpocetine), Celebrex $100 \mathrm{mg}$ cap. (celecoxib), Celipres $100 \mathrm{mg}$ tab. (celiprolole $\mathrm{HCl}$ ), Cholestil max $200 \mathrm{mg}$ tab. (hymecromon), Cuprenil $250 \mathrm{mg}$ tab. (penicillamine), Cyclonamide $250 \mathrm{mg}$ tab. (etamsylate), Darunavir $800 \mathrm{mg}$ tab. (darunavir), Digavar $100 \mathrm{mg}$ tab. (aceclofenac), DIH $500 \mathrm{mg}$ tab. (diosmine), Doloxib $60 \mathrm{mg}$ tab. (etoricoxib), Duloxetine $60 \mathrm{mg}$ cap. (duloxetine), Emanera $20 \mathrm{mg}$ cap. (esomeprazole), Epitoram $200 \mathrm{mg}$ tab. (topiramate), Etfarm $1000 \mathrm{mg}$ tab. (metformine $\mathrm{HCl}$ ), Finxta $5 \mathrm{mg}$ tab. (finasteride), Imigran FDT $100 \mathrm{mg}$ tab. (sumatriptane), Gabitril $15 \mathrm{mg}$ tab. (tiagabinum), Karnidin $20 \mathrm{mg}$ tab. (lercanidipine $\mathrm{HCl}$ ), Lacipil $4 \mathrm{mg}$ tab. (lacidipine), Lacosamide $200 \mathrm{mg}$ tab. (lacosamide), Lamotrix $100 \mathrm{mg}$ tab. (lamotrigine), Lisihexal $10 \mathrm{mg}$ tab. (lisinopril), Nabuton VP $500 \mathrm{mg}$ tab. (nabumetone), Nebicard $5 \mathrm{mg}$ tab. (nebivolol), Noflamen $15 \mathrm{mg}$ tab. (meloxicam), Opacorden $200 \mathrm{mg}$ tab. (amiodarone $\mathrm{HCl}$ ), Petinimid cap. $250 \mathrm{mg}$ (ethosuximide), Piroxicam Jelfa $10 \mathrm{mg}$ tab. (piroxicam), Plaquenil $200 \mathrm{mg}$ tab. (hydroxychloroquine), Polfenon $300 \mathrm{mg}$ tab. (propafenone $\mathrm{HCl}$ ), Polfilin prolongatum $400 \mathrm{mg}$ tab. (pentoxifylline), Propranolol WZF $40 \mathrm{mg}$ tab. (propranolol $\mathrm{HCl}$ ), Radirex $12 \mathrm{mg}$ tab. (11.30-13.90 mg derivatives of hydroksyanthracene calculated for rhein/tab.), Raenom $7.5 \mathrm{mg}$ tab. (ivabradine), Sectral $200 \mathrm{mg}$ tab. (acebutolol), Senzop $7.5 \mathrm{mg}$ tab. (zopiclone), Seractil $400 \mathrm{mg}$ tab. (dexibuprofen), Sermion $10 \mathrm{mg}$ tab. (nicergoline), Sevemed $800 \mathrm{mg}$ tab. (sevelamer), Simvagen $20 \mathrm{mg}$ tab. (simvastatine), Spamilan $10 \mathrm{mg}$ tab. (buspirone $\mathrm{HCl}$ ), Sulpiryd Hasco $200 \mathrm{mg}$ tab. (sulpiride), Sumamigren $100 \mathrm{mg}$ tab. (sumatriptane), Tenofovir $245 \mathrm{mg}$ tab. (tenofovir disoproxil), Tiocolis $8 \mathrm{mg}$ tab. (thiocolchicoside), Valdix extract $355 \mathrm{mg}$ tab. (valerianae extr.), Viregyt-K $100 \mathrm{mg}$ cap. (amantadine $\mathrm{HCl}$ ), Zonisamidum $100 \mathrm{mg}$ cap. (zonisamide), Zyloric $100 \mathrm{mg}$ tab. (allopurinol). 


\section{Initial screening of antimicrobial activity}

The initial study was carried out with 6 standard strains: B. subtilis, S. aureus, E. coli, P. aeruginosa, $C$. albicans and $A$. brasiliensis. A concentration of $3.2 \mathrm{mg} / \mathrm{mL}$ active substance in the testing medium was assumed as the upper limit for all investigated medicines. The suspensions of the selected drugs were prepared in $0.08 \mathrm{M}$ phosphate buffer, $\mathrm{pH}$ 7 , to achieve a final concentration of $3.2 \mathrm{mg} / \mathrm{mL}$ active substance in the agar medium. Mueller-Hinton II agar was used for bacteria while Sabourand agar was used for fungal strains. Microbial cells were harvested from the appropriate agar medium to prepare the cell suspensions. Once the agar medium settled, $2 \mu \mathrm{L}$ suspensions of the standard strains, at a density of 0.5 on the McFarland scale, were dropped onto the agar surface. The plates with bacterial strains were incubated at $37^{\circ} \mathrm{C}$ for $24 \mathrm{~h}$; fungal strains were incubated at $30^{\circ} \mathrm{C}$ for $72 \mathrm{~h}$. The medicines for which no growth was observed for at least one of the tested strains were selected for further investigation including bacterial probiotic strains.

\section{Determination of the minimal inhibitory concentration (MIC) of active substances present in the medicinal products}

The MIC values of the active substances present in the medicinal products were calculated by the evaluation of growth inhibition of tested strains on Mueller-Hinton II agar (for bacterial strains), Sabourand agar (for fungal strains), and MRS agar (for probiotic strains) supplemented with double dilutions of the medicine product suspensions according to the CLSI guidelines (25).

Microbial suspensions, at a density 0.5 McFarland units, were diluted $1: 10$ and $2 \mu \mathrm{L}$ of the obtained suspensions were applied onto the surfaces of agar plates containing the appropriate concentrations of active substances in analyzed preparations (from $3.2 \mathrm{mg} / \mathrm{mL}$ to $0.0125 \mathrm{mg} / \mathrm{mL}$ ). The inoculated plates were incubated either at $37^{\circ} \mathrm{C}$ for $24 \mathrm{~h}$ (bacterial strains), at $30^{\circ} \mathrm{C}$ for $72 \mathrm{~h}$ (fungal strains), or at $37^{\circ} \mathrm{C}$ for $72 \mathrm{~h}$ in an atmosphere with $5 \% \mathrm{CO}_{2}$ added (probiotic strains). The MIC value is defined as the lowest concentration of the active substance that prevents the visible growth of the microorganisms.

\section{RESULTS AND DISCUSSION}

Our previous research used the disc-diffusion method as a screening assay, in which paper discs were soaked with a $10 \%(\mathrm{v} / \mathrm{v})$ solution of the tested drugs (7-14). However, this method is much less precise than the evaluation of bacterial growth on an agar medium supplemented with the investigated drug. Therefore, in the current study, the initial screening assay was performed by suspending each drug sample in an agar medium containing the relevant active substance at a concentration of $3.2 \mathrm{mg} /$ $\mathrm{mL}$, which was assumed as the upper limit.

Potential growth inhibition was examined for a total of 59 medicinal products belonging to different drug groups when tested against six standard strains. It turned out that preparations containing the following active substances: aceclofenac, acetylsalicylic acid, amantadine hydrochloride, amiodarone hydrochloride, amlodipine, betaxolol, celecoxib, dexibuprofen, duloxetine, esomeprazole, hydroxyanthracene derivatives, hydroxychloroquine, lamotrigine, losartan potassium, nicergoline, nimesulide, phenylbutazone, piroxicam, propafenone hydrochloride, propranolol hydrochloride, propylthiouracil, simvastatin, tenofovir disoproxil, tiagabine, and zonisamide, in concentrations $\leq 3.2 \mathrm{mg} / \mathrm{mL}$ inhibited the growth of at least one of the tested strains. The MICs of the active substances in the pharmaceutical products against all examined standard microbial strains are shown in Table 1.

The majority of the tested compounds, with the exception of simvastatin and amantadine, inhibited the growth of B. subtilis ATCC 6633. The second most sensitive strain was $S$. aureus ATCC 6538, whose bacterial growth was inhibited by 21 of the 25 examined compounds (no inhibition in case of amiodarone, simvastatin, hydroxychloroquine, or amantadine). The highest activities against all tested strains were found in the cases of the antihypertensive compound amlodipine (MICs 0.1-0.2 mg/mL), the antidepressant duloxetine (MICs $0.2-1.6 \mathrm{mg} / \mathrm{mL}$ ), and the beta-blocker propranolol (MICs $0.4-1.6 \mathrm{mg}$ / $\mathrm{mL}$ ). Hydroxyanthracene derivatives, which are used as laxatives, inhibited the growth of all tested bacteria, including probiotic strains, at very low concentrations (MICs 0.0125-0.4 mg/mL). This result suggests that long-term use of these compounds may disturb the balance of natural microbiota and probiotic bacteria in the intestine. Moreover, genotoxic and carcinogenic activities of hydroxyanthracene derivatives, for example in aloe extract, have been detected, hence the safety of using these compounds in foods is questioned (26).

Aceclofenac and phenylbutazone from the group of anti-inflammatory compounds, as well as the proton pump inhibitor, esomeprazole, inhibited growth of all Gram-positive bacteria, with MIC values: $(0.2-1.6 \mathrm{mg} / \mathrm{mL}) ;(0.8-3.2 \mathrm{mg} / \mathrm{mL})$ and $(1.6-$ $3.2 \mathrm{mg} / \mathrm{mL})$, respectively. Growth inhibition of all 
Table 1. Antimicrobial activity of selected non-antibiotic drugs

\begin{tabular}{|c|c|c|c|c|c|c|c|c|c|}
\hline \multirow[b]{2}{*}{$\begin{array}{c}\text { Pharmaceutical group* } \\
\text { - active substance } \\
\text { (pharmaceutical product) }\end{array}$} & \multicolumn{9}{|c|}{$\begin{array}{l}\text { Minimal inhibitory concentration in } \mathrm{mg} / \mathrm{mL} \\
\text { of active substance present in the pharmaceutical products }\end{array}$} \\
\hline & 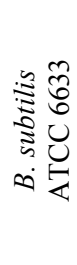 & 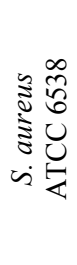 & 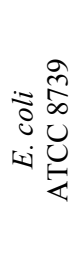 & 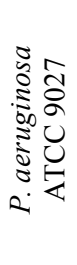 & 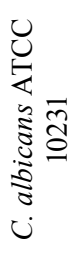 & 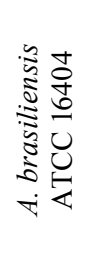 & 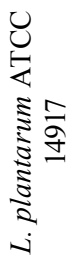 & 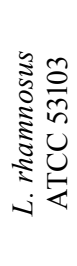 & 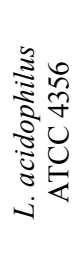 \\
\hline \multicolumn{10}{|c|}{ Analgeticum, Antiphlogisticum* } \\
\hline $\begin{array}{l}\text { - acetylsalicylic acid } \\
\text { (Acard } 75 \mathrm{mg} \text { tab.) }\end{array}$ & 3.2 & 3.2 & 3.2 & 3.2 & 3.2 & NA** & 3.2 & NA & 3.2 \\
\hline $\begin{array}{l}\text { - dexibuprofen } \\
\text { (Seractil } 400 \text { mg tab.) }\end{array}$ & 1.6 & 3.2 & NA & NA & 3.2 & 0.8 & 1.6 & 1.6 & 1.6 \\
\hline $\begin{array}{c}\text { - aceclofenac } \\
\text { (Digavar } 100 \text { mg tab.) }\end{array}$ & 0.2 & 0.4 & NA & NA & NA & 1.6 & 0.4 & 0.4 & 0.4 \\
\hline $\begin{array}{l}\text { - nimesulide } \\
\text { (Anulin } 100 \text { mg tab.) }\end{array}$ & 3.2 & 3.2 & NA & NA & NA & NA & NA & NA & NA \\
\hline $\begin{array}{l}\text { - phenylbutazon } \\
\text { (Butagran equi } 200 \mathrm{mg} / \mathrm{g} \text { oral } \\
\text { powder) }\end{array}$ & 0.8 & 0.8 & NA & NA & NA & NA & 3.2 & 3.2 & 3.2 \\
\hline \multicolumn{10}{|c|}{ Antiarrhytmicum } \\
\hline $\begin{array}{c}\text { - amiodarone } \mathrm{HCl} \\
\text { (Opacorden } 200 \mathrm{mg} \mathrm{tab} \text {.) }\end{array}$ & 1.6 & NA & NA & NA & NA & NA & 0.8 & 0.8 & 0.8 \\
\hline $\begin{array}{l}\text { - propranolol } \mathrm{HCl} \\
\text { (Propranolol WZF } 40 \mathrm{mg} \text { tab.) }\end{array}$ & 0.4 & 0.8 & 0.4 & 1.6 & 0.8 & 0.8 & 0.8 & 0.8 & 0.4 \\
\hline $\begin{array}{c}\text { - propafenone } \mathrm{HCl} \\
\text { (Polfenon } 300 \text { mg tab.) }\end{array}$ & 0.4 & 0.4 & 1.6 & NA & 0.4 & 0.8 & 0.8 & 1.6 & 0.4 \\
\hline \multicolumn{10}{|c|}{ Antiatheromaticum } \\
\hline $\begin{array}{c}\text { - simvastatine } \\
\text { (Simvagen } 20 \text { mg tab.) }\end{array}$ & NA & NA & NA & NA & 3.2 & NA & NA & NA & NA \\
\hline \multicolumn{10}{|c|}{ Antidepressivum } \\
\hline $\begin{array}{c}\text { - duloxetine } \\
\text { (Duloxetine } 60 \mathrm{mg} \text { cap.) }\end{array}$ & 0.2 & 0.4 & 0.4 & 1.6 & 0.4 & 0.8 & 0.4 & 0.4 & 0.4 \\
\hline \multicolumn{10}{|c|}{ Antiepilepticum } \\
\hline $\begin{array}{c}\text { - zonisamide } \\
\text { (Zonisamidum } 100 \mathrm{mg} \text { cap.) }\end{array}$ & 1.6 & 1.6 & NA & NA & NA & 3.2 & NA & NA & 3.2 \\
\hline $\begin{array}{l}\text { - lamotrigine } \\
\text { (Lamotrix } 100 \mathrm{mg} \text { tab.) }\end{array}$ & 0.4 & 0.2 & 0.8 & 3.2 & NA & NA & NA & NA & NA \\
\hline $\begin{array}{c}\text { - tiagabine } \\
\text { (Gabitril } 15 \text { mg tab.) }\end{array}$ & 0.4 & 0.4 & NA & NA & 3.2 & 3.2 & 0.8 & 0.8 & 0.4 \\
\hline \multicolumn{10}{|c|}{ Antiglauconicum } \\
\hline $\begin{array}{c}\text { - betaxolol } \mathrm{HCl} \\
\text { (Betamoxyl } 20 \mathrm{mg} \text { tab.) }\end{array}$ & 3.2 & 3.2 & 3.2 & NA & NA & 3.2 & 3.2 & 3.2 & 3.2 \\
\hline \multicolumn{10}{|c|}{ Antihypertensivum } \\
\hline $\begin{array}{l}\text { - losartan potassium } \\
\text { (Xartan } 50 \mathrm{mg} \text { tab.) }\end{array}$ & 3.2 & 3.2 & NA & NA & NA & NA & NA & 1.6 & 1.6 \\
\hline $\begin{array}{c}\text { - amlodipine } \\
\text { (Amlopin } 10 \mathrm{mg} \text { tab.) }\end{array}$ & 0.1 & 0.1 & 0.2 & 0.2 & 0.1 & 0.1 & 0.1 & 0.2 & 0.1 \\
\hline \multicolumn{10}{|c|}{ Antimalaricum } \\
\hline $\begin{array}{l}\text { - hydroxycloroquine sulfate } \\
\text { (Plaquenil } 200 \mathrm{mg} \text { tab.) }\end{array}$ & 3.2 & NA & NA & NA & NA & NA & NA & NA & 3.2 \\
\hline
\end{tabular}


Table 1. Antimicrobial activity of selected non-antibiotic drugs; cont.

\begin{tabular}{|c|c|c|c|c|c|c|c|c|c|}
\hline \multirow[b]{2}{*}{$\begin{array}{c}\text { Pharmaceutical group* } \\
\text { - active substance } \\
\text { (pharmaceutical product) }\end{array}$} & \multicolumn{9}{|c|}{$\begin{array}{l}\text { Minimal inhibitory concentration in } \mathrm{mg} / \mathrm{mL} \\
\text { of active substance present in the pharmaceutical products }\end{array}$} \\
\hline & 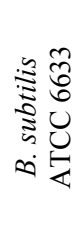 & 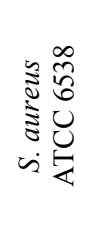 & 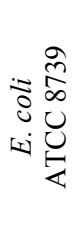 & 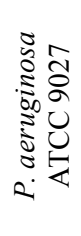 & 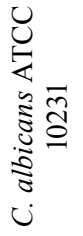 & 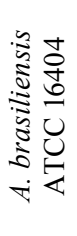 & 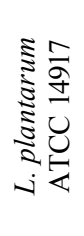 & 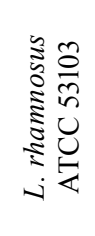 & 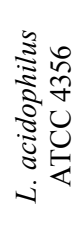 \\
\hline \multicolumn{10}{|c|}{ Antiphlogisticum } \\
\hline $\begin{array}{c}\text { - celecoxib } \\
\text { (Celebrex } 100 \mathrm{mg} \text { cap. })\end{array}$ & 0.4 & 0.4 & NA & NA & NA & 0,8 & NA & 1.6 & 1.6 \\
\hline $\begin{array}{l}\text { - piroxicam } \\
\text { (Piroxicam } 10 \mathrm{mg} \mathrm{tab.)}\end{array}$ & 0.4 & 0.4 & NA & NA & NA & NA & NA & NA & NA \\
\hline \multicolumn{10}{|c|}{ Antisecretoricum } \\
\hline $\begin{array}{l}\text { - esomeprazole } \\
\text { (Emanera } 20 \text { mg cap.) }\end{array}$ & 1.6 & 1.6 & NA & NA & NA & NA & 3.2 & 1.6 & 3.2 \\
\hline \multicolumn{10}{|c|}{ Laxans } \\
\hline $\begin{array}{l}\text { - hydroxyanthracene } \\
\text { derivatives } \\
\text { - total Rhei Radix } \\
\text { (Radirex } 12 \text { mg tab.) }\end{array}$ & $\begin{array}{c}0.05 \\
2\end{array}$ & $\begin{array}{c}0.025 \\
1\end{array}$ & $\begin{array}{c}0.4 \\
16\end{array}$ & $\begin{array}{l}0.2 \\
8\end{array}$ & NA & NA & $\begin{array}{c}0.1 \\
4\end{array}$ & $\begin{array}{c}0.0125 \\
0.5\end{array}$ & $\begin{array}{c}0.05 \\
2\end{array}$ \\
\hline \multicolumn{10}{|c|}{ Thyreostaticum } \\
\hline $\begin{array}{l}\text { - propylthiouracyl } \\
\text { (Thyrosan } 50 \mathrm{mg} \mathrm{tab.)}\end{array}$ & 1.6 & 3.2 & NA & NA & NA & NA & 0.4 & 0.4 & 0.4 \\
\hline \multicolumn{10}{|c|}{ Vasodilatans } \\
\hline $\begin{array}{c}\text { - nicergoline } \\
\text { (Sermion } 10 \mathrm{mg} \mathrm{tab.)}\end{array}$ & 0.4 & 0.4 & NA & NA & 0.8 & 1.6 & 0.8 & 0.8 & 0.8 \\
\hline \multicolumn{10}{|c|}{ Virustaticum } \\
\hline $\begin{array}{c}\text { - tenofovir disoproxil } \\
\text { (Tenofovir } 245 \mathrm{mg} \text { tab.) }\end{array}$ & 1.6 & 1.6 & 3.2 & 3.2 & NA & NA & NA & 3.2 & 3.2 \\
\hline $\begin{array}{c}\text { - amantadine } \mathrm{HCl} \\
\text { (Viregyt-K } 100 \text { mg cap.) }\end{array}$ & NA & NA & 3.2 & 3.2 & 1.6 & NA & NA & NA & 3.2 \\
\hline
\end{tabular}

(*) the names of pharmaceutical groups, according to Podlewski et al. (38).

$(* *)$ NA - Lack of microbial growth inhibition in the medium supplemented with a medicinal product containing active substance in concentration $3.2 \mathrm{mg} / \mathrm{mL}$.

Gram-positive bacteria and fungi strains was observed in the case of the following compounds: dexibuprofen (MICs 0.8-3.2 $\mathrm{mg} / \mathrm{mL}$ ), the anticonvulsant tiagabine (MICs $0.4-3.2 \mathrm{mg} / \mathrm{mL}$ ), and the vasodilator nicergoline (MICs 0.4-1.6 mg/mL). Propranolol, propafenone, and duloxetine were active against fungal strains at concentrations of $0.4-0.8 \mathrm{mg} / \mathrm{mL}$. The antiviral compound tenofovir was active against the majority of bacterial strains in high concentrations only (MICs $1.6-3.2 \mathrm{mg} / \mathrm{mL}$ ), a result that is beneficial in the case of probiotic bacteria.

In the group of probiotic strains, L. plantarum was the least sensitive to the tested compounds and L. acidophilus was the most sensitive. In general, if a tested compound showed activity against
Gram-positive bacteria then it was also active in similar concentrations against the majority of probiotic strains. In some cases, e.g., propylthiouracil and amiodarone, the activity against probiotic strains was even higher than for other bacteria tested. However, the anticonvulsant compound lamotrigine was found to be exceptional in that it inhibited Gram-positive strains, in concentrations from 0.2 to $0.8 \mathrm{mg} / \mathrm{mL}$, while all probiotic strains showed low sensitivity to this agent. Since the probiotic strains are our symbionts and protect the human intestines (18), treatment with lamotrigine may be quite favorable in the case of longterm use (continuous dosing of lamotrigine applies to antiepileptic treatment and the prevention of depressive episodes in patients with bipolar I disorder). 
The recent review of Lagadinou et al. (27) focuses on the antibacterial activity of several non-antibiotics divided into different therapeutic groups. In the group of anti-inflammatory drugs, the most active was ibuprofen that inhibited the growth of $E$. coli at a concentration of $0.002 \mathrm{mg} / \mathrm{mL}$ and, simultaneously, reduced adhesion of $E$. coli to uroepithelial cells. Moreover, ibuprofen was active against $S$. aureus, Microsporum spp., and dermatophyte Trichophyton spp. (27). In our investigation, the ibuprofen derivative dexibuprofen did not inhibit the growth of $E$. coli at a concentration of $3.2 \mathrm{mg} / \mathrm{mL}$, however, it was active against all tested Gram-positive bacteria, including probiotic strains (MICs 1.6-3.2 mg/mL) and fungal strains (C. albicans $\mathrm{MIC}=3.2 \mathrm{mg} / \mathrm{mL}$ and $A$. brasiliensis $\mathrm{MIC}=0.8 \mathrm{mg} / \mathrm{mL}$ ).

In previous studies, it was found that the common cardiovascular drug amlodipine inhibited several bacteria strains (MIC 0.025-0.8 mg/mL) (28). Also, Yi et al. (29) investigated the effects of amlodipine against MRSA strains $(\mathrm{MIC}=0.128 \mathrm{mg} / \mathrm{mL})$ and found that amlodipine inhibited a wide range of $\beta$-lactamases. In our work, we found that amlodipine, in addition to being active against pathogenic bacterial strains (MICs $0.1-0.2 \mathrm{mg} / \mathrm{mL}$ ), is also active against fungi $(\mathrm{MIC}=0.1 \mathrm{mg} / \mathrm{mL})$ and Lactobacillus strains (MICs 0.1-0.2 mg/mL).

It is already known that non-antibiotics may increase the activity of certain chemotherapeutics against some bacterial strains. For example, omeprazole and nizatidine improve the action of metronidazole against $H$. pylori strains (30), whereas phenothiazines may be helpful in the treatment of diseases caused by multidrug-resistant Gram-negative rods (31). Furthermore, synergistic effects between loperamide and cephalosporins and tetracyclines against E. coli MC1061 (32), as well as synergism between vaniline and spectinomycin against a multidrugresistant strain of $E$. coli (33), have been described. Taking into account the increase in microbial resistance to the most commonly used antibiotics and chemotherapeutics, synergistic interactions may be a solution for improving the treatment of bacterial diseases.

Regarding our research on the effects of nonantibiotics on probiotic strains, the obtained observations are completely new. There are limited studies concerning the influence of natural compounds from food on growth inhibition in pathogenic strains, as well as improved growth of probiotic Lactobacillus strains, e.g., phenolic compounds, particularly from mango (34) and many polyphenols from nuts, cereals, vegetables, and fruits. (35).
Taking into consideration the pharmaceutical analysis of medicinal products, especially microbial purity or sterility testing, the antimicrobial activity of non-antibiotic preparations should be neutralized $(36,37)$. Therefore, prior to testing microbial purity or sterility, each medicinal product should be checked for possible antimicrobial activity. In the case of tablets and capsules, which were analyzed in this study, antimicrobial activity relates directly to the active substances. No preservative was present in the tested preparations. For the preparations with antimicrobial activity at a concentration equal or higher than the 10 -fold stock solution $(1 \mathrm{~g} / 10 \mathrm{~mL})$, a method of antimicrobial activity neutralization was developed to make the results of the microbial purity reliable (36, 37). For the preparations containing dexibuprofen, phenylbutazone, amiodarone, esomeprazole, propylthiouracil, and tenofovir, the most advantageous solution was a buffer with neutralizers (tween $80-$ $3 \%$, soy lecithin $-0.3 \%$, histidine $-0.1 \%$ ). However, in the case of preparations containing propranolol, tiagabine, amlodipine, celecoxib, piroxicam, or nicergoline, the antimicrobial activity was removed by simultaneously using a buffer with neutralizers and a 10 -fold dilution of the sample. For the formulations containing the following active substances: aceclofenac, propafenone, duloxetine, lamotrigine, and hydroxyanthracene derivatives, the only effective method of removing antimicrobial activity was membrane filtration.

\section{CONCLUSION}

Some of the tested non-antibiotic medicinal products possess essential antimicrobial activity. Aceclofenac, propafenone, duloxetine, amlodipine, and hydroxyanthracene derivatives inhibited the growth of at least four tested strains at concentrations below $0.8 \mathrm{mg} / \mathrm{mL}$. Hydroxyanthracene derivatives contained in Radirex tablets were highly active (MICs 12.5-100 $\mu \mathrm{g} / \mathrm{mL}$ ) against Gram-positive bacteria, including probiotic strains.

\section{Conflict of interest}

The authors declare no conflicts of interest.

\section{REFERENCES}

1. Kristiansen J.E.: ASM NEWS 57, 135 (1991).

2. Williams J.D.: J. Antimicrob. Chemother. 35, 721 (1995).

3. Guttmann P., Ehrlich, P.: Berliner Klinische Wochenschrift 39, 953 (1891). 
4. Hendricks O., Butterworth TS., Kristiansen JE.: Int. J. Antimicrob. Agents 22, 242 (2003).

5. Chakrabarty A.N., Molnar J., Dastidar S.G., Motobashi N.: Non Antibiotics a new class of unrecognised antimicrobics. National Institute of Science Communication, New Delhi, India (1998).

6. Tyski S.: Acta Poloniae Pharm. 66, 401 (2003).

7. Kruszewska H., Zaręba T., Tyski S.: Acta Pol. Pharm. Drug Res. 57 supl., 117 (2000).

8. Kruszewska H., Zaręba T., Tyski S.: Acta Pol. Pharm. Drug Res. 59, 436 (2002).

9. Kruszewska H., Zaręba T., Tyski S.: Acta Pol. Pharm. Drug Res. 61 supl., 436 (2004).

10. Kruszewska H., Zaręba T., Tyski S.: Acta Pol. Pharm. Drug Res. 63, 457 (2006).

11. Kruszewska H., Zaręba T., Tyski S.: Farmaceutyczny Przegląd Naukowy 37, 19 (2008).

12. Kruszewska H., Zaręba T., Tyski S.: Acta Pol. Pharm. Drug Res. 65, 779 (2008).

13. Kruszewska H., Zaręba T., Tyski S.: Acta Pol. Pharm. Drug Res. 67, 733 (2010).

14. Kruszewska H., Zaręba T., Tyski S.: Acta Pol. Pharm. Drug Res. 69, 1368 (2012).

15. Gocmen S.J; Buyukkocak, U., Caglayan O., Aksoy A., J. Dermatol. Treat.: 19, 351 (2008).

16. Laudy A., Mrówka A., Krajewska J. Tyski S.: PLOS ONE 11, e0147131 (2016).

17. Laudy A., Kuklińska E., Tyski S.: Molecules 22, 114 (2017).

18. Behnsen J., Deriu E., Sassone-Corsi M., Raffatellu M.: Probiotics: Properties; Examples; and Specific Applications. Cold Spring Harb. Perspect. Med. 3, a010074 (2013).

19. Capurso L.: J. Clin. Gastroenterol 53, Supp. 1 (2019).

20. Shaaban M., El-Rhman OAA., Al.-Qaidi B., Ashour HM.: Microorganisms, 8, 960 (2020).

21. Wasfi R., El-Rhman OAA., Zafer MM., Ashour HM.: J. Cell. Mol. Med. 22, 3, 1972 (2018).

22. Huang Y., Wang J., Quan G., Wang X., Yang L., Zhong L.: Appl. Environ. Microbiol. 80, 24, 7496 (2014).
23. Hassan A., Din AU., Zhu Y., Zhang K., Li T., Wang Y., Xu S., Lei H., Yu X., Wang G.: Appl. Microbiol. Biotechnol. 104, 6337 (2020).

24. Mantzourani I., Kazakos S., Terpou A., Alexopoulos A., Bezirtzoglou E., Bekatorou A., Plessas S.: Foods 8, 4 (2019).

25. Clinical and Laboratory Standards Institute; Methods for dilution antimicrobial susceptibility tests for bacteria that grow aerobically; approved standard 10th ed. Document M7-A10. Wayne, PA: CLSI; 2015.

26. Younes M. et al.: EFSA Journal 16 (1) e05090 (2018).

27. Lagadinou M., Onisor MO., Rigas A., Musetescu DV., Gkentzi D., Panos G., Marangos M.: Antibiotics 9, 107 (2020).

28. Kumar A ol. 52 (3), 285 (2003).

29. Yi Z., Pei Z., Xiaoyan M.: Int. J. Pharmacy and Chemistry 5 (1), 12 (2019).

30. Chen M., Jensen B., Zhai L., Colding H., Kristiansen JE.: Int. J. Antimicrob. Agents 19, 195 (2002).

31. Comes J., Beelman R.: J. Food Prot. 65 (3), 476 (2002).

32. Ejim L., Farha MA., Falconer SB., Wildenhain J., Coombes BK., Tyers M., Brown ED., Wright GD.: Nature Chemical Biology 7, 348 (2011).

33. Brochado A.R. et al.: Nature 559 (7713) (2018).

34. Pacheco-Ordaz R., Wall-Medrano A., Goni MG, Ramos-Clamont M.G., Ayala-Zavala JF., Gonzales-Aguilar GA.: Lett. Appl. Microbiol 66, 25 (2017).

35. Piekarska-Radzik L., Klewicka E.: Eur. Food Res. Technology 247, 9 (2021).

36. European Pharmacopoeia 10 ed. (2020).

37. Clonts L.: Microbial Limit and Bioburden Tests: Validation approaches and global requirements, Interpharm Press, Inc., Buffalo Grove (1998).

38. Podlewski J.K., Chwalibogowska - Podlewska A.: Leki Współczesnej Terapii, ed. Split Trading (2004). 